\title{
Effects of Liming on Physicochemical Properties and Nutrient Availability of Acidic Soils in Welmera Woreda, Central Highlands of Ethiopia
}

\author{
Kebede Dinkecha ${ }^{1}$, Dereje Tsegaye ${ }^{2}$ \\ ${ }^{1}$ Department of Agricultural Chemistry, Melkassa Agriculture Research Centre, Adama, Ethiopia \\ ${ }^{2}$ Departments of Applied Chemistry, Adama Science and Technology University, Adama, Ethiopia
}

Email address:

2013kebededinkecha@gmail.com (K. Dinkecha)

\section{To cite this article:}

Kebede Dinkecha, Dereje Tsegaye. Effects of Liming on Physicochemical Properties and Nutrient Availability of Acidic Soils in Welmera Woreda, Central Highlands of Ethiopia. Biochemistry and Molecular Biology. Vol. 2, No. 6, 2017, pp. 102-109. doi: $10.11648 /$ j.bmb.20170206.16

Received: September 9 2017; Accepted: October 8, 2017; Published: December 4, 2017

\begin{abstract}
Soil acidity is one of chemical soil degradation problems which affect productivity of the soil in Ethiopian highlands. The purpose of this research was to identify the status of soil acidity and determine the amount of lime requirement for neutralization to increase plant nutrient availability in Welmera woreda, Oromia region. More specifically the study pointed out statistically, the nutrient availability before and after liming acidic soil using paired $t$-test. The results indicated that the soil of study area was strongly acidic $\left(\mathrm{pH}\left(\mathrm{H}_{2} \mathrm{O}\right)<5.3\right)$ and exchangeable acidity was from $2.86 \pm 0.01-3.55 \pm 0.07 \mathrm{cmol} / \mathrm{Kg}$. The soil showed low concentration of plant nutrients $(\mathrm{AP}, \mathrm{TN}, \mathrm{K}, \mathrm{Ca}, \mathrm{Mg}$ ) and high in micronutrients $(\mathrm{Cu}, \mathrm{Fe}, \mathrm{Mn}$, and $\mathrm{Zn})$ contents. After 90 days liming in greenhouse incubation of the soil samples, the results showed effective neutralization of the soil, which indicated it was properly limed and the effects of soil acidity on nutrient availability was clearly observed. The concentration of all anions (AP, TN, and OC), cations $\left(\mathrm{Na}^{+}, \mathrm{K}^{+}, \mathrm{Ca}^{+2}\right.$ and $\mathrm{Mg}^{+2}$ ) and micronutrients were found to be significantly different except TN and OC, between the soil samples for before and after liming. After limed acidic soils, anion and cations are improved their availability for plant while micronutrients are decreased from toxicity to normal condition.
\end{abstract}

Keywords: Acidity, Incubation, Liming, Lime Materials, Soil pH

\section{Introduction}

Soil acidity is one of the major limiting factors to acid sensitive crop production in the western highland of Oromia Region, Ethiopia. It is often developed in regions where excessive rainfall coupled with that removes appreciable amounts of exchangeable basic ions like calcium $(\mathrm{Ca})$, magnesium $(\mathrm{Mg})$, sodium $(\mathrm{Na})$ and potassium $(\mathrm{K})$ from the surface of soil. Its severity is extremely variable due to the effects of parent materials, land form, vegetation and climate pattern [18]. Its effects on crop growth are those related to the deficiency of major nutrients and the toxicity of aluminum ( $\mathrm{Al}$ ), manganese $(\mathrm{Mn})$ and hydrogen $(\mathrm{H})$ ions in the soil to plant physiological processes [16]. In order to secure sustainable crop production and reasonable yield, acidic soils have to be corrected by addition of agricultural lime to a $\mathrm{pH}$ range which is suitable for better yield of crop production [16]. Measuring lime requirement and estimating the level of acid saturation together with exchangeable acidity are the most common methods to alleviate soil acidity constraints to crop production [1]. Agricultural liming material is the most common soil management practices whose addition to agricultural soil in moderate amounts may be beneficial as plant nutrients, minimize soil acidification. The beneficial effects of liming soil are neutralization of exchangeable $\mathrm{Al}$, increase $\mathrm{Ca}, \mathrm{Mg}, \mathrm{P}$ and $\mathrm{Mo}$ availability, stimulate microbiological activity in soil; improve physical structure of soil by clumping together or flocculation, clay in to more stable aggregates.

Liming raises the soil $\mathrm{pH}$ by adding calcium \& magnesium to soil and causes the aluminium and manganese to go out from the soil solution back in to precipitate then, solid (non- 
toxic) chemical forms. The lime requirement will vary depending upon the types of soil, the desired change in $\mathrm{pH}$, buffering capacity of the specific soil, type of liming material, and the fineness or texture of the lime material [3].

Once this amount is determined, a liming material must be selected that will economically satisfy the soil test recommendation and result in maximum, efficient production.

Frequency of liming is influenced by soil texture, rate of crop removal of $\mathrm{Ca}$ and $\mathrm{Mg}$, amount of lime applied, quality of lime applied, soil buffer capacity, tillage and desired $\mathrm{pH}$ range [3]. Since all lime stones are not the same, the quality of lime varies significantly and should be an important consideration in lime management. Four factors are most important in assessing lime quality; chemical purity, speed of reaction, calcium and magnesium content, and moisture [24].

In the area even though excess natural and manmade fertilizer were used, soil fertility and crop productivity were decreased from year to year. Before 15 years ago the area was known by high productivity of cereal crops and high land pulse crops, but now day the cereal crop productivity was very low while high land pulse and oil crops were almost diminution their productivity. Some unpublished studied reports on that area were also indicated the areas were under the risk in soil fertility and crop productivity. Information on the extent of soil acidity problem on plant nutrients availability and the amount of lime requirement to neutralize this soil in the area is generally little.

Although studying soil acidity problems and quantitative analysis using soil laboratory tests and green house experiment to acquire solutions for this problem was very little. This study was important to understanding the chemistry of plant nutrients when acid soils are limed for successful soil fertility management. Therefore, the present study explored the effects of lime to soil physicochemical properties and acid saturation under greenhouse conditions in western Shoa highland.

\section{Materials and Methodology}

\subsection{Description of Study Area}

The study was conducted in Welmera Woreda, central high land of Ethiopia. The woreda is located at a distance of around $34 \mathrm{~km}$, west of the capital Addis Ababa. Geographically, the study area was located $9^{0} 05^{\prime} 55^{\prime \prime} \mathrm{N}, 38^{0} 36^{\prime} 211^{\prime \prime} \mathrm{E}$ and altitudes $2556 \mathrm{~m}$ above sea level. The mean annual temperature of the woreda was $21.3^{\circ} \mathrm{C}$ and annually about $1100 \mathrm{~mm}$ rain fall received, and the rain pattern in distribution (short and long rainy season). The dominant soils of the area are reported to be nitisols which are sesquioxidic and moderately to strongly acidic [25]. These soils have high clay content (35-56\%), homogenous, highly developed medium angular blocky structures, and are silt clay to clay in texture.

The economic activities of the local society of the study area are primarily mixed farming systems that involve animal husbandry and crop production. The major crops are teff (Eragrostistef), barley (Hordeumvulgare), wheat
(Triticumaestivum), faba bean (Phaseoluslunatus), maize (Zea mays) and potato (Solanumtubersoum) [17].

\subsection{Soil Sampling}

A total of five representative fields were selected from two kebeles, Minjaro (Kata), Gefersa Minjaro and Gutu from wetabacha minjaro kebele and Kore and Gudu from Ade Simbirit Kotu kebele which are named as sample site Minjaro, GM, Gutu, Kore and Gudu respectively. From each site, eight to fifteen sub-samples were composited by a radial sampling scheme using an auger [29].

A total of five composite samples (about $9.5 \mathrm{~kg}$ ) for liming and physicochemical analysis and fifteen cores for bulk density in three depths and cane sampling for moisture analysis were collected randomly from around 127 hector of welmera woreda, bedi area at the depth of $0-30 \mathrm{~cm}$. The samples were air dried gently crushed (ground) in to fine texture and homogenized and sieved by using $0.25 \mathrm{~mm}$ mesh size sieve. From the sieved samples about $0.5 \mathrm{Kg}$ were preserved in labelled plastic bags for laboratory analysis and $3 \mathrm{Kg}$ per pot were limed in greenhouse incubation [1].

\subsection{Soil Physical Properties Analysis}

Soil moisture and bulky density were determined by using oven dry method while soil texture was analyzed by hydrometer after soil soaked by calgon solution and dispersed by mechanical stirrer [4].

\subsection{Soil Chemical Properties Analysis}

The soil $\mathrm{pH}$ was measured potentiometrically with a digital $\mathrm{pH}$ meter in the supernatant suspension of $1: 2.5$ soils to water ratio [12].

Soil organic carbon content was determined by the dichromate oxidation and organic matter was estimated from the organic carbon content by multiplying the latter by 1.724 . Total $\mathrm{N}$ was determined using the micro-Kjeldahl digestion, distillation and titration procedure as described by Bremner and Mulvaney [6]. Soils available $P$ was extracted by the Bray-II method [5] were quantified using spectrophotometer (wave length of $880 \mathrm{~m}$ ) calorimetrically using the mixture of ammonium molybedate, sulphuric acid and potassium antimony tartrate as an indicator.

Exchangeable basic ( $\mathrm{Ca}, \mathrm{Mg}, \mathrm{K}$ and $\mathrm{Na}$ ) ions were extracted using $1 \mathrm{M}$ ammonium acetate $\left(\mathrm{NH}_{4} \mathrm{OAc}\right)$ solution at $\mathrm{pH}$ 7. The extracts of $\mathrm{Ca}$ and $\mathrm{Mg}$ ions were determined using AAS while $\mathrm{K}$ and $\mathrm{Na}$ were determined by flame photometer. To determine the cation exchange capacity (CEC), the soil samples were first leached with $\mathrm{M} \mathrm{NH}_{4} \mathrm{OAC}$, washed with ethanol and the adsorbed ammonium was replaced by sodium [21]. The CEC was then measured titrimetrically by distillation of ammonia that was displaced by $\mathrm{Na}$ following the micro- Kjeldahl procedure. Total exchangeable acidity was determined by saturating the soil samples with $1 \mathrm{M} \mathrm{KCl}$ solution and titrating with $0.02 \mathrm{M} \mathrm{HCl}$ as described by Rowell [23]. From the same extract, exchangeable $\mathrm{Al}$ in the soil was titrating with a standard 
solution of $0.02 \mathrm{M} \mathrm{HCl}$.

\subsection{Determination of Lime Requirements for Neutralization of Acid Soil}

The lime material used for this experiment was pure $\mathrm{CaCO}_{3}$ with $100 \% \mathrm{CCE}$ which bought from the factory and 3 $\mathrm{kg}$ of soil sample per pot.

The lime recommendation on this study was based on the amount of exchangeable acidity $(3.22-3.55 \mathrm{cmol} / \mathrm{kg})$ measured by the lime requirement soil test and initial soil $\mathrm{pH}\left(4.9-5.3 \mathrm{H}_{2} \mathrm{O}\right)$.

The liming materials $\left(\mathrm{CaCO}_{3}\right.$ contain $\left.100 \% \mathrm{CCE}\right)$ and soil samples were ground to fine texture pass through $0.5 \mathrm{~mm}$ sieve.

The five soil samples were replicated to fifteen and lime materials were added at different rates $(1.5 \mathrm{~g}, 2 \mathrm{~g}$ and $2.5 \mathrm{~g})$ in each pot and incubated in green house for 90 days. The incubated samples were mixed and wetted by adding water with the interval of 2-3 days to increase the speed of reaction between acidic soil and lime at the field capacity moisture and soil $\mathrm{pH}$ was tested within two weeks interval. Finally, liming in the greenhouse incubation of soil samples were stopped when the $\mathrm{pH}$ of all samples reached target $\mathrm{pH}$ (6.87.2) by $\mathrm{pH}\left(\mathrm{H}_{2} \mathrm{O}\right)$ and $(6.4-6.8)$ by $\mathrm{pH}(\mathrm{KCl})$ methods and the important parameters, which were determined before liming were again analysed to identify the effects of lime on soil physicochemical properties [1].

Lime requirement (LR) was determined by the following formula [13]:

$L R . \mathrm{CaCO}_{3}(\mathrm{Kg} / \mathrm{ha})=\frac{E A(\mathrm{cmol} / \mathrm{Kg}){ }^{*} 0.15 \mathrm{~m}^{*} 10^{4} \mathrm{~m}^{2 *} \mathrm{BD}\left(\mathrm{mg} / \mathrm{m}^{3}\right){ }^{*} 1000}{2000 \mathrm{cmol} / \mathrm{Kg}}$

Where, EA - Exchangeable Acidity BD - Bulk Density LR - Lime Requirements

Recovery tests for the Uv-visible spectrophotometer, Atomic absorption spectroscopy and Flame Photo meter methods were performed for soil samples using non-spiked and spiked samples in order to ascertain the reliability and efficiency of the analytical procedures for analyzing soil samples before liming and after liming.

Important instrument such as Uv-visible spectrophotometer for phosphorous analysis, flame photometer for sodium and potassium determination and atomic absorption spectrophotometer for $\mathrm{Ca}, \mathrm{Mg}$ and micronutrient were calibrated by using standard solution [30].

Statistical analysis of the data was carried out by one-way analysis of variance (ANOVA) using spss statics SAS software for comparing nutrient variation among the different sample sites while t-test use to compare the mean concentration of nutrient before and after liming acidic soil [20].

\section{Results}

Table 1. The mean $\pm S D$ results of soil physical properties.

\begin{tabular}{|c|c|c|c|c|c|c|}
\hline \multirow{2}{*}{ sample } & \multirow{2}{*}{$\%$ Moisture } & \multirow{2}{*}{$\mathrm{BD}\left(\mathrm{g} / \mathrm{cm}^{3}\right)$} & \multicolumn{4}{|l|}{ Texture } \\
\hline & & & \% Clay & $\%$ Silt & $\%$ Sand & S. Class \\
\hline Minjaro & $38.2 \pm 1.1$ & $1.13 \pm 0.013$ & 42.75 & 38.75 & 18.5 & Clay \\
\hline GM & $41.8 \pm 0.91$ & $1.2 \pm 0.016$ & 43.25 & 36.75 & 20 & Silt-Clay \\
\hline Gutu & $38.1 \pm 1.58$ & $1.14 \pm 0.014$ & 43.5 & 37.25 & 19.25 & Clay \\
\hline Kore & $39.9 \pm 1.14$ & $1.19 \pm 0.004$ & 44 & 38.50 & 17.5 & Clay \\
\hline Gudu & $37.3 \pm 1.8$ & $1.21 \pm 0.006$ & 43.75 & 36.50 & 19.75 & Clay \\
\hline
\end{tabular}

BD- Bulk Density and S. Class- Soil Class

Table 2. The average status of soil acidity and $\mathrm{pH}$ by both water and $\mathrm{KCl}$ before liming.

\begin{tabular}{|c|c|c|c|c|c|c|c|}
\hline Sample Site & Exch. Acidity (cmol/Kg) & Exch. $\mathbf{A l}^{+3}(\mathrm{cmol} / \mathrm{Kg})$ & Exch. $\mathbf{H}^{+}(\mathrm{cmol} / \mathrm{Kg})$ & $\mathrm{pH}(\mathrm{KCl})$ & $\mathrm{pH}\left(\mathrm{H}_{2} \mathrm{O}\right)$ & $\mathbf{A P}(\mathbf{p p m})$ & $\% \mathrm{TN}$ \\
\hline Minjaro & $3.22 \pm 0.01$ & $2.23 \pm 0.04$ & $0.99 \pm 0.07$ & 4.1 & 4.9 & $7.4 \pm 0.1$ & $0.22 \pm 0.002$ \\
\hline GM & $2.86 \pm 0.02$ & $1.6 \pm 0.01$ & $1.26 \pm 0.03$ & 4.06 & 4.9 & $9.6 \pm 0.075$ & $0.18 \pm 0.003$ \\
\hline Gutu & $3.49 \pm 0.02$ & $2.1 \pm 0.01$ & $1.48 \pm 0.04$ & 4.04 & 5.1 & $10.47 \pm 0.048$ & $0.16 \pm 0.005$ \\
\hline Kore & $3.21 \pm 0.07$ & $2.3 \pm 0.06$ & $0.91 \pm 0.06$ & 4.07 & 5.3 & $9.72 \pm 0.093$ & $0.21 \pm 0.004$ \\
\hline Gudu & $3.16 \pm 0.07$ & $1.89 \pm 0.01$ & $1.27 \pm 0.08$ & 4.01 & 5.06 & $8.51 \pm 0.16$ & $0.19 \pm 0.002$ \\
\hline
\end{tabular}

$\mathrm{Cmol} / \mathrm{Kg}$ - Cent mole per Kilogram of soil TN - Total Nitrogen AP - Available Phosphorous

Exch. $\mathrm{Al}^{+3}$ and $\mathrm{H}^{+}$- Exchangeable aluminium and hydrogen

Table 3. The mean \pm SD of exchangeable cations and micronutrient before liming.

\begin{tabular}{|c|c|c|c|c|c|c|c|c|c|}
\hline \multirow{2}{*}{$\begin{array}{l}\text { Sample } \\
\text { site }\end{array}$} & \multicolumn{5}{|c|}{ Exchangeable cations (ppm) } & \multicolumn{4}{|c|}{ Micronutrients (ppm) } \\
\hline & $\mathrm{Na}$ & $\mathbf{K}$ & Ca & Mg & CEC & Fe & Mn & $\mathbf{C u}$ & Zn \\
\hline Minjaro & $1.7 \pm 0.02$ & $5.7 \pm 0.02$ & $24 \pm 0.08$ & $17.3 \pm 0.06$ & $86.4 \pm 1.53$ & $208.7 \pm 2.47$ & $107.2 \pm 2.73$ & $6.08 \pm 0.017$ & $2.6 \pm 0.069$ \\
\hline GM & $1.1 \pm 0.01$ & $6.2 \pm 0.03$ & $20.6 \pm 0.08$ & $9.17 \pm 0.07$ & $77.0 \pm 1.64$ & $190.1 \pm 2.43$ & $130.01 \pm 2.17$ & $4.56 \pm 0.016$ & $2.4 \pm 0.048$ \\
\hline Gutu & $1 \pm 0.02$ & $6.1 \pm 0.02$ & $26.9 \pm 0.03$ & $13.8 \pm 0.09$ & $78.7 \pm 1.51$ & $207.7 \pm 2.83$ & $114.07 \pm 3.41$ & $4.83 \pm 0.023$ & $2.3 \pm 0.068$ \\
\hline Kore & $1.3 \pm 0.01$ & $5.1 \pm 0.03$ & $30.4 \pm 0.02$ & $16.6 \pm 0.06$ & $105.1 \pm 1.4$ & $202.9 \pm 1.95$ & $105.71 \pm 2.89$ & $6.14 \pm 0.034$ & $2.7 \pm 0.063$ \\
\hline Gudu & $1 \pm 0.01$ & $5.8 \pm 0.09$ & $25.7 \pm 0.02$ & $12.7 \pm 0.09$ & $97.0 \pm 2.03$ & $192.7 \pm 3.29$ & $102.44 \pm 2.65$ & $4.73 \pm 0.017$ & $2.01 \pm 0.059$ \\
\hline
\end{tabular}

CEC- Cation exchangeable capacity 
Table 4. A greenhouse incubation of liming acid soil as a function of duration with pH change.

\begin{tabular}{lll}
\hline Liming time(days) & $\mathbf{p H}(\mathbf{K C l})$ & Temp. $\left({ }^{\circ} \mathbf{C}\right)$ \\
\hline BL & $4.1-4.3$ & 23 \\
14 & $4.2-4.4$ & 22 \\
28 & $4.57-4.72$ & 23 \\
42 & $4.7-4.9$ & 23 \\
56 & $5.1-5.3$ & 23 \\
70 & $5.6-5.9$ & 23 \\
84 & $6.4-6.9$ & 22 \\
\hline
\end{tabular}

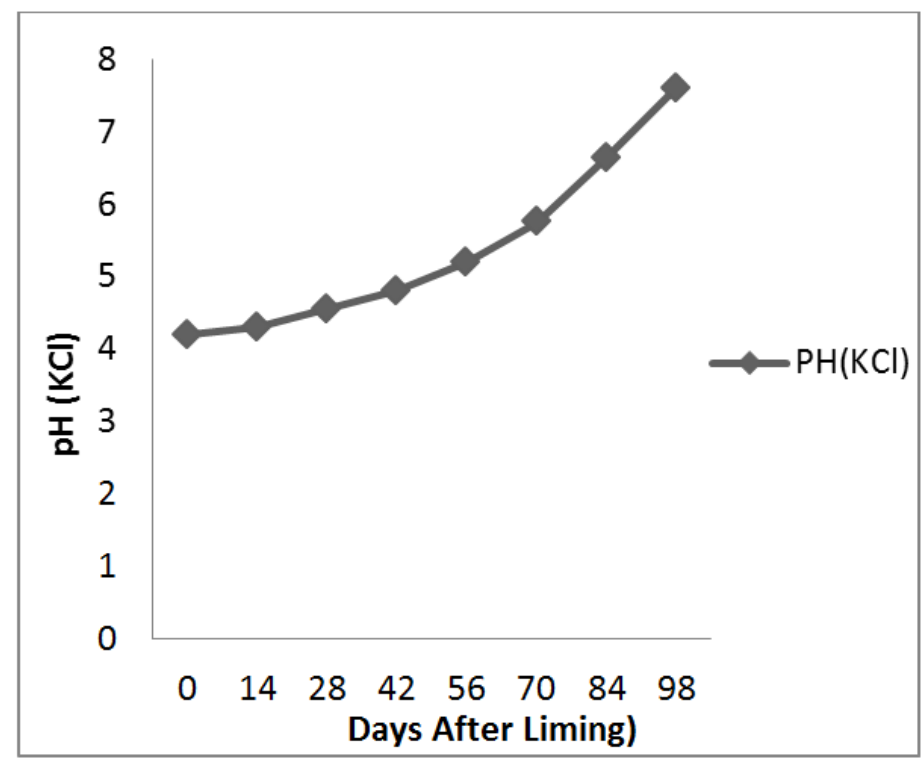

Figure 1. The effects of liming incubation time on soil acidity.

Table 5. The effects of liming on some selected soil chemical properties.

\begin{tabular}{|c|c|c|c|c|c|}
\hline \multirow{2}{*}{ Parameters } & \multicolumn{2}{|l|}{ Mean \pm SE } & \multicolumn{2}{|c|}{ Paired t-Test } & \multirow{2}{*}{$\begin{array}{l}\text { Difference } \\
\text { Significant }\end{array}$} \\
\hline & BL & $\mathbf{A L}$ & $\mathbf{t}_{\text {crit }}$ & $\mathbf{t}_{\mathrm{cal}}$ & \\
\hline $\mathrm{pH}\left(\mathrm{H}_{2} \mathrm{O}\right)$ & $5.05 \pm 0.06$ & $7.36 \pm 0.17$ & 2.13 & 34.60 & $*$ \\
\hline $\mathrm{pH}(\mathrm{KCl})$ & $4.06 \pm 0.04$ & $6.88 \pm 0.08$ & 2.13 & 63.70 & $*$ \\
\hline Exch. Acid $\left(\mathrm{cmolkg}^{-1}\right)$ & $3.19 \pm 0.021$ & $0.73 \pm 0.006$ & 2.13 & 14.70 & $*$ \\
\hline Exch. $\mathrm{Al}\left(\mathrm{cmolkg}^{-1}\right)$ & $1.98 \pm 0.04$ & $0.027 \pm 0.003$ & 2.13 & 30.09 & $*$ \\
\hline$\% \mathrm{OC}$ & $1.24 \pm 0.001$ & $1.23 \pm 0.007$ & 2.13 & 1.51 & ns \\
\hline$\% \mathrm{TN}$ & $0.16 \pm 0.003$ & $0.23 \pm 0.007$ & 2.13 & 4.00 & $*$ \\
\hline $\mathrm{AP}(\mathrm{ppm})$ & $9.14 \pm 0.075$ & $20.85 \pm 0.004$ & 2.13 & 8.10 & * \\
\hline
\end{tabular}

BL-Before Liming AL-After Liming * Significant different ns-No significant difference

Table 6. Comparison of the exchangeable cations and micronutrients before and after liming.

\begin{tabular}{lllll}
\hline Parameters & Mean \pm SE $(\mathbf{p p m})$ & & Paired t-Test & \\
\hline & BL & AL & tcrit & tcal \\
\hline $\mathrm{Na}$ & $1.2 \pm 0.002$ & $10.46 \pm 0.07$ & 2.13 & 57.87 \\
$\mathrm{~K}$ & $5.78 \pm 0.003$ & $14.58 \pm 0.042$ & 2.13 & 23.20 \\
$\mathrm{Ca}$ & $25.52 \pm .004$ & $171 \pm 0.083$ & 2.13 & 18.97 \\
$\mathrm{Mg}$ & $13.91 \pm 0.061$ & $39.81 \pm 0.3$ & 2.13 & 16.72 \\
$\mathrm{CEC}$ & $85.52 \pm 0.019$ & $244.14 \pm 0.054$ & 2.13 & 7.30 \\
$\mathrm{Cu}$ & $5.276 \pm 0.004$ & $2.53 \pm 0.078$ & 2.13 & 26.44 \\
$\mathrm{Fe}$ & $200.304 \pm 0.095$ & $30.456 \pm 0.071$ & 2.13 & 37.55 \\
$\mathrm{Mn}$ & $112.044 \pm 1.86$ & $23.488 \pm 0.175$ & 2.13 & $*$ \\
$\mathrm{Zn}$ & $2.402 \pm 0.048$ & $1.44 \pm 0.003$ & 2.13 & $*$ \\
\hline
\end{tabular}

CEC - Cation exchangeable capacity tcal - t-calculate tcrt - t-crtical

\section{Discussion}

Calibration of instrument using working standard solution was done for Uv-Visible spectrophotometer, flame photometry and atomic absorption spectrophotometry which are used to determine the concentrations of available phosphorous, exchangeable cations and micronutrients in soil 
samples respectively. The linear correlation coefficients obtained, ranging between $0.9973-0.9996$, are in acceptable ranges [30].

The recovery tests for soil samples were performed for evaluation of analytical methods and the result were within the range of $88.7 \%$ to $111 \%$ for both soil samples before and after liming and the recovery for all plant nutrients are within the acceptable range $(80-120 \%)$ [30].

Soil physical properties was shown in Table 1 and soil moisture contents are found to be within the range of $37.3 \%$ to $41.7 \%$, are higher than normal nitosol, which is moisture $28.72-32.64 \%$ [10]. This is due to the nature of soil type (class) which contains high silt and clay particles, low infiltration capacity and good water holding capacity. In this study, the results of soil bulk density are found to be in the $1.1-1.2 \mathrm{~g} / \mathrm{cm}^{3}$ and its low for all sample sites as shown in Table 1. This is due to high clay and silt contents of soil and compactness that occupy small volume [8]. In this study the soil samples have high clay contents about $43.5 \%$, moderate silt about $36.75 \%$ and low sand contents, about $18.5 \%$, which show a soil class of clay or nitosol [27].

The status of soil acidity, $\mathrm{pH}$, Total Nitrogen and Available phosphorous content were shown in Table 2. The results of this study indicate that the $\mathrm{pH}$ of the study area is below 5.5 and acid cations such as $\mathrm{H}^{+}$and $\mathrm{Al}^{+3}$ are responsible for such acidity. As shows in Table 2, the concentration of exchangeable $\mathrm{Al}^{+3}$ is high (2.33 to 2.85 $\mathrm{cmol} / \mathrm{Kg}$ ) indicating $\mathrm{Al}$ toxicity to be expected in the area. This result in agreement with the result of, Susolski [22] who reported exchangeable $\mathrm{Al}^{+3}$ as $2.76 \pm 0.17$ and total exchangeable acidity as $3.19 \pm 0.93 \mathrm{cmol} / \mathrm{Kg}$. So, high exchange between acid cations $\left(\mathrm{Al}^{+3}\right.$ and $\left.\mathrm{H}^{+}\right)$and basic cations $\left(\mathrm{Na}^{+}, \mathrm{K}^{+}, \mathrm{Ca}^{+2}, \mathrm{Mg}^{+2}\right.$ and $\left.\mathrm{NH}_{4}^{+}\right)$is expected and $\mathrm{Al}^{+3}$ toxicity may affect the availability of basic cations especially during plant roots uptake of the nutrients.

Exchangeable acidity indicates the presence of excess $\mathrm{Al}^{+3}$ and $\mathrm{H}^{+}$ion on the soil colloid as compared to total cation exchange capacity (CEC) of the soil and the acid cations are occupy the site of basic cations. So, in this study area, there is high exchangeable acidity and acid saturation percentage [9]. This needs ameliorative measures like liming.

A greenhouse incubation of liming acid soil as a function of duration with $\mathrm{pH}$ change was shown in Table 3 and Figure 1. Liming raises the soil $\mathrm{pH}$ by adding calcium \& magnesium to soil and causes the aluminum and manganese to go from the soil solution back in to solid (non-toxic) chemical forms. In this study the change in soil $\mathrm{pH}$ due to lime materials application results were recorded within two weeks intervals and the result indicates that the soil $\mathrm{pH}$ increases as liming time increases. However, the change (increases) of soil $\mathrm{pH}$ in the first two months was lower than the remaining month. This might be due to strength of exchangeable acid in the first time and after long time interaction of lime materials and acid cations and the acid became weak and change of soil $\mathrm{pH}$ is expected to increase rapidly as it is shown in Figure 1.

This study shows that the farmers must stay at least more than two months after applying lime to sow their seeds.
Except sun light variation and lime application rates, target $\mathrm{pH}$ and the decrease in the exchangeable acidity attains its minimum value at 90 days of incubation period. After 90 days of incubation the $\mathrm{pH}(\mathrm{KCl})$ is 6.8 and exchangeable acidity is $0.93 \mathrm{Cmol} / \mathrm{Kg}$ in the soils. The application of lime materials in greenhouse incubation for 90 days neutralized the acid soil by increasing soil $\mathrm{pH}$ and decreasing exchangeable $\mathrm{Al}^{+3}$. Lime $\left(\mathrm{CaCO}_{3}\right)$ reacts with $\mathrm{H}^{+}$in soil solution to produce $\mathrm{H}_{2} \mathrm{O}$ and $\mathrm{CO}_{2}$ and also convert $\mathrm{Al}^{3+}$ from toxic to none toxic forms [23].

Comparison of exchangeable acidity and anions before liming and after liming was shown in Table 5 and paired ttest results reveal that significant differences are observed in the $\mathrm{pH}$, total exchangeable acidity, exchangeable $\mathrm{Al}^{+3}$, available phosphorous, and total nitrogen concentrations between soil samples before and after liming, while there is no significant difference between the soil sample before and after liming, in their organic carbon content. The average $\mathrm{pH}$ $\left(\mathrm{H}_{2} \mathrm{O}\right)$ was $5.05 \pm 0.06$ and $7.36 \pm 0.07$ for before and after liming, respectively, which shows the area, was strongly acidic.

Like soil $\mathrm{pH}$, exchangeable $\mathrm{H}^{+}$and $\mathrm{Al}^{+3}$ show high significant difference between before and after liming. From total exchangeable acidity, exchangeable $\mathrm{Al}^{+3}$ is reduced from $1.98 \pm 0.04$ to $0.027 \mathrm{cmol} / \mathrm{Kg}$ and exchangeable $\mathrm{H}^{+}$was reduced from $3.19 \pm 0.01$ to $0.73 \pm 0.01 \mathrm{cmol} / \mathrm{Kg}$, after a greenhouse incubation liming of acid soil. This indicates exchangeable acidity, which dominates the area is removed from the soil. On the other hand, after liming, the availability of basic cations show increase as exchangeable acidities are decreased, to maintain positive and negative charge neutrality in soil solutions [1].

Similar conclusion was reached by Simard et al. [20] who observed no effect of liming on OC content of the acidic soil. For all soil sample sites increasing the soil $\mathrm{pH}$ due to applied agricultural lime show a significant effect on total $\mathrm{N}$ content. This may be due to $\mathrm{N}$ losses from the soil and decreased $\mathrm{N}$ fixation due to less bacterial action in acid soil.

However, phosphorous availability is significantly affected by soil acidity. The phosphorous concentration is found to be roughly doubled after liming for all soil sample sites (Table 5). This is due to the nature of existence of phosphorous in soil. The existence of $\mathrm{P}$ is highly limited by soil $\mathrm{pH}$. At $\mathrm{pH}<$ $5.5 \mathrm{P}$ exists in the form of $\mathrm{AlPO}_{4}$ and $\mathrm{FePO}_{4}$, while at $\mathrm{pH}>$ 5.5 it exists in the form of $\mathrm{Ca}_{3}\left(\mathrm{PO}_{4}\right)_{2}, \mathrm{H}_{2} \mathrm{PO}_{4}{ }^{-}$and $\mathrm{HPO}_{4}{ }^{-2}$. On the other hand, there is a high competition between acid cations such as $\mathrm{Al}^{+3}, \mathrm{Fe}^{+3}$ and basic cations such as $\mathrm{Na}^{+}, \mathrm{K}^{+}$, $\mathrm{Ca}^{+2}$ and $\mathrm{Mg}^{+2}$ to be bonded to $\mathrm{PO}_{4}{ }^{-3}$.

According to Haynes et al [9] at low soil $\mathrm{pH}, \mathrm{Al}$ and $\mathrm{Fe}$ are highly soluble and react with phosphorous to form insoluble $\mathrm{AlPO}_{4}$ and $\mathrm{FePO}_{4}$, which are precipitates and could not be absorbed by plant roots. Absorption of $\mathrm{PO}_{4}^{-3}$ by plant roots depends on root length and hairs (branches) on the root. This is due to the less mobile nature of phosphate ion and it could not move towards to plant roots rather than plant roots are moves towards to $\mathrm{PO}_{4}^{-3}$ to uptake it [30]. In this study, the mean $\mathrm{P}$ concentration in limed soil sample is higher $(20.85$ 
ppm) than before liming (9.14 ppm) which clearly shows highly significant effects of soil acidity on $\mathrm{P}$ availability and this is agreement with reported by [2].

In this study concentration of sodium is found to be 0.12 and $10.6 \mathrm{ppm}$ and potassium are (5.67 and $14.58 \mathrm{ppm}$ ) for before and after liming, which shows significant difference indicating that the soil acidity affecting the sodium and potassium availability due to insolubility of $\mathrm{Na}^{+}$and $\mathrm{K}^{+}$at low $\mathrm{pH}$, leaching easily by high rain fall and replacement by soluble $\mathrm{H}^{+}$and $\mathrm{Al}^{+3}$ in water solution [12]. In this study, $\mathrm{Ca}$ concentration before liming acid soil $(25.5 \pm 0.002 \mathrm{ppm})$ and after liming $(171 \pm 2.7 \mathrm{ppm})$ clearly indicates the effects of soil acidity on calcium availability. The increasing exchangeable calcium availability during greenhouse incubation for liming soil acidity is due to soil $\mathrm{pH}$ increase and this is also for phosphorous availability and plant root uptake of $\mathrm{PO}_{4}^{-3}$ in the form of $\mathrm{Ca}_{3}\left(\mathrm{PO}_{4}\right)_{2}$. According to Hue [8] calcium phosphate easily release phosphate ion to plant roots while $\mathrm{AlPO}_{4}$ and $\mathrm{FePO}_{4}$ are precipitated and do not release $\mathrm{PO}_{4}{ }^{-3}$ to plant roots. On the other hand, the highest significant difference between mean concentrations of calcium (25.5 and $171 \mathrm{ppm}$ ) before and after liming is due to the increase in the solubility of $\mathrm{Ca}$ at higher $\mathrm{pH}$ [24].

In this study there is significant difference between CEC concentration before and after liming (Table 6). The highest significant difference of CEC before and after liming is due to low $\mathrm{pH}$, exchangeable acid cations such as $\mathrm{H}^{+}$and $\mathrm{Al}^{+3}$ increase and occupies the site of basic cations [24]. However, after 90 days greenhouse incubation acid cations leave the sites and replaced by basic cations in the soil solution. The result of this study shows that the mean concentration of CEC changes from $85.52 \pm 0.019$ to $244.14 \pm 0.054 \mathrm{ppm}$ before and after liming, respectively, which indicates soil acidity highly affects CEC availability.

Like exchangeable cations, micronutrients such as $\mathrm{Cu}, \mathrm{Fe}$, $\mathrm{Mn}$ and $\mathrm{Zn}$ are significantly different before and after liming (Table 6). Considering the mean results of Fe concentration, the highest (200.17 ppm) and lowest (190.08 ppm) for soil samples of the study area, are in agreement with the study of Birhanu [3] for the same range of soil $\mathrm{pH}$. Similarly, the highest (130.01 ppm) and lowest (102.44 ppm) concentration is recorded for Mn before liming. The results of this study show that among the four micronutrients, iron and copper are significantly high in soil samples before liming. The highest concentration of all micronutrient elements ( $\mathrm{Fe}, \mathrm{Cu}, \mathrm{Mn}$, and $\mathrm{Zn}$ ) recorded in acid soil is due to the availability of these nutrients at low pH. McDowell [18] reported the concentration of micronutrients are 3.10, 197.63, 117.31 and $1.58 \mathrm{ppm}$ for $\mathrm{Cu}, \mathrm{Fe}, \mathrm{Mn}$ and $\mathrm{Zn}$ respectively, which is in agreement with this study which gives of 2.956, 200.3, 112.04 and 1.44 ppm for $\mathrm{Cu}, \mathrm{Fe}, \mathrm{Mn}$ and $\mathrm{Zn}$, respectively. In this study, the result recorded for $\mathrm{Mn}$ and Fe before liming are high (112.04 ppm and $200.3 \mathrm{ppm}$ ) respectively, which shows at low $\mathrm{pH}$ both nutrients are highly soluble.

In this study, the effects of $\mathrm{pH}$ and soil acidity on micronutrients availability are clearly observed tcalculated $>$ t-critical shows high significant difference as shown in Table 6. All micronutrients concentration in acid soil of $\mathrm{pH}\left(\mathrm{H}_{2} \mathrm{O}\right)<5.3$ is higher than limed soil in the greenhouse incubation with $\mathrm{pH}\left(\mathrm{H}_{2} \mathrm{O}\right)>6.8$. The highest concentration of $\mathrm{Fe}$ and $\mathrm{Mn}(200.03 \mathrm{ppm})$ and (112.04 ppm) in soil acidity of before liming are indicators of the increasing in concentration of micronutrients as soil $\mathrm{pH}$ decreases.

However, after 90 days greenhouse incubation of liming acid soil, the low mean concentration is recorded for $\mathrm{Fe}$ (30.45 ppm) and $\mathrm{Mn}(23.87 \mathrm{ppm})$ as the $\mathrm{pH}$ increases to 7.3 at this $\mathrm{pH}, \mathrm{Fe}$ and $\mathrm{Mn}$ insoluble and replaced by $\mathrm{Ca}^{+2}$ ion found in lime. Similarly, the results of $\mathrm{Cu}$ and $\mathrm{Zn}$ concentration are decreases almost by half $(5.276 \pm 0.004$ to $2.53 \pm 0.078 \mathrm{ppm}$ and $2.402 \pm 0.048$ to $1.44 \pm 0.003 \mathrm{ppm})$ after liming respectively as shown in Table 6 . The greatest difference of micronutrients before and after liming indicates the status of soil acidity in the study area is significantly affecting micronutrients availability [21]. Table 6, clearly illustrates that, as soil $\mathrm{pH}$ increases due to liming, the availability of exchangeable cations also increases, while the availability of micronutrients decreases as soil $\mathrm{pH}$ increases.

\section{Conclusion}

This study assesses lime requirement and its effect on plant nutrient availability. The results reveal that soils in all of the sample sites are acidic $\mathrm{pH}\left(\mathrm{H}_{2} \mathrm{O}\right)<5.3$ with low concentration of soil macro nutrients. It is found that the average values of exchangeable acidity and exchangeable $\mathrm{Al}$ show results within the ranges $3.49-2.86 \mathrm{cmol} / \mathrm{Kg}$ and 2.3 $1.86 \mathrm{cmol} / \mathrm{Kg}$ respectively.

From this study, it is observed that soil acidity and liming factor directly affect plant nutrients. As compared by paired t-test, except OC all macro and micronutrients are significantly affected by soil acidity. Application of lime results in reduction of exchangeable acidity, Al saturation and thereby increasing soil $\mathrm{pH}$. In addition, treatment of acidic soil with lime result in an increase in the concentration of the exchangeable cations $\left(\mathrm{Na}^{+}, \mathrm{K}^{+}, \mathrm{Ca}^{+2}\right.$ and $\left.\mathrm{Mg}^{+2}\right)$ and decrease micronutrients $(\mathrm{Cu}, \mathrm{Fe}, \mathrm{Mn}$ and $\mathrm{Zn})$ in the soil solutions, from exchange complex to the levels required and increasing nutrient availabilities for plant uptakes.

After 90 days greenhouse incubation of liming acid soil, all limed soils attain the target $\mathrm{pH} 6.9$ and decrease in exchangeable acidity to $0.93 \mathrm{cmol} / \mathrm{Kg}$ and $\mathrm{Al}$ to $0.027 \mathrm{cmol} / \mathrm{kg}$. During application of lime, soil $\mathrm{pH}$ increases slightly in the first two months and fastly increases after two months due to a slight decrease in the strengths of acidity as liming period increases.

So, the farmer must stay at least two months after applying the lime to sow his/her seeds. This is due to the reaction between lime materials and soil acidity is slow and time dependent reaction. To validate the findings of the present greenhouse incubation study and for the profitability of acid sensitive crops production, farmers may need to apply optimum lime to the soils under study.

This study area is found to be medium to high in $\mathrm{N}$ and $\mathrm{P}$ 
content after liming acid soil. Therefore, in this area it is recommended to use liming instead of applying more fertilizers for increase crop productivity.

Exchangeable cations and micronutrient before liming were indicated in Table 3 and the concentrations of available phosphorous, potassium, calcium and CEC are low. This is due to low $\mathrm{pH}$ and high exchangeable acidity. According to Landon [15], the top soils having AP and CEC of $>25,15-25$ $\mathrm{cmol} / \mathrm{kg}, 5-15 \mathrm{cmol} / \mathrm{kg}$ and $<5 \mathrm{cmol} / \mathrm{kg}$ are classified as high, medium, low and very low, respectively. Based on the above ratings, the soils of all the site of the study area qualify for low status (less than $15 \mathrm{ppm}$ and $15 \mathrm{cmol} / \mathrm{Kg}$ ) for AP and CEC, respectively as it is shown in Table 2 and 3 . However, micronutrients such as iron and manganese concentration are very high $(208.17 \pm 11.37-190.08 \pm 21.43 \quad \mathrm{ppm})$ and $(130.01 \pm 7.17-102.44 \pm 7.65 \mathrm{ppm})$ respectively. Similarly the concentration of $\mathrm{Fe}$ and $\mathrm{Mn}>66.5 \mathrm{ppm}$ was classified as high and based on this classification; the results of Fe and Mn, in all sample sites are high as shown in Table 3.

\section{References}

[1] Achalu C., (2012). Effects of Liming on Acidity-Related Chemical Properties of Soils of Different Land Use Systems in Western Oromia, Ethiopia. World Journal of agricultural society Vol. 8(6) pp. 560-567.

[2] Adane B. (2014). Effects of Liming Acidic Soils on Improving Soil Properties and Yield of Haricot Bean. Ethiopian Institute of Agricultural Research, Holetta ARC, Addis Ababa, Ethiopia. J Environ Anal Toxicology 4:248. doi: 10.4172/2161-0525.1000248

[3] Birhanu A. (2010). Soil Acidity Problems and Comparison of Lime Requirement, Determination Methods in Different Land Use in Fagetalekoma Woreda, Awi Zone, Amhara Region, Environmental Science Program, MSc. Thesis Submitted to School of Graduate Studies of AAU.

[4] Bouyoucos, G. (1962). Hydrometer method improvement for making particle size analysis of soils. Agronomy Journal Vol. 54 (1) pp. 54-57.

[5] Bray, R.. (1945). Determination of total organic and available phosphorous in soil (4th ed.). London: London Academic Press.

[6] Bremner, J. M. and C. S. Mulvaney, (1982). Nitrogen- Total. In: Page, A. L., R. H. Miller and D. R. Keeney (eds). Methods of Soil Analysis, Part 2. American Society Agronomy. Madison, Wiscosin, pp: 595-624.

[7] David, E. Kissel and Paul F. Vendrell,. ( 2012). Agricultural and Environmental Services Laboratories and Determining Lime Requirement Using the Equilibrium Lime Buffer Capacity (LBCEq).

[8] Desta, B. (2002). Effect of Liming and N and P Fertilization on Grain Yield of Barley in Ethiopian. Journal of Agricultural SciencesVol. 15) pp. 11-15.

[9] Haynes, J. R. (2001). Amelioration of aluminum toxicity and $\mathrm{P}$ deficiency in acid soils by additions of organic residues critical review of the phenomenon and the 22 mechanisms involved. Kluwer Academic Publishers Netherlands.
[10] Heluf G. and Kibebow, K. (2012). Effects of Liming on Acidity-Related Chemical Properties of Soils of Different Land Use Systems in Western Oromia, Ethiopia.

[11] Hue, N. V. ( 1998). Managing manganese toxicity in former sugarcane soils on Oahu. University of Hawaii at Manoa, College of Tropical Agriculture and Human Resources, publication SCM-1. p. 7.

[12] Huluka, G. (2005). A Modification of the Adams-Evans Soil Buffer Determination Solution. Communications in Soil Science and Plant Analysis (Vol. 36) pp. 949-951.

[13] Kamprath, E. J. (1984). Crop Response to Lime in the Tropics. In: Adams, F., Ed., Soil Acidity and Liming, 2nd Edition, Agronomy Monograph 12, Agronomy and Soil Science Society of America, Madison, 349-368.

[14] Ketterings, Q. M. ( 2005). Soil pH in field crops. Cornel University, College of Agriculture and Life Science, Department of crop and soil science, Cornel nutrient analysis laboratory Ithaca, NY 14853, Agronomy Fact Sheet $S$.

[15] Landon, J. ). (1991). Booker tropical soil manual: A Handbook for Soil Survey and Agricultural Land Evaluation in the Tropics and Subtropics. Longman Scientific and Technical, Essex, New York. ( ${ }^{\text {rd }}$ Edition).

[16] Mesfin, A. (2009). Methods of Soil Analysis, Part 1: Physical and Mineralogical Methods, Cantarella, eds. Plant-Soil Interactions at Low pH. Campinas, Brazil: Brazilian So. (2nd editio, Ed.).

[17] MoFED, (2002). Ministry of Finance and Economic Development). Ethiopia: Sustainable Development and Poverty Reduction Program (SDPRP). Addis Ababa, Ethiopia.

[18] Rowell, D. L., 1994. Soil Science: Methods and Application, Addison Wesley Longman, Limited England.

[19] SAS Institute (2004). SAS User's Guide, Statistics central \& western Ethiopia, utilization of diversity in Version 9.1. (Ed.). SAS Inst., Cary, NC, USA.

[20] Simard, R. C. (1994). Effect oftillage, lime and phosphorus on soil $\mathrm{pH}$ and mehlich-3 Ababa, Ethiopia. extractable nutrients. Commun. Soil Sci. extractable nutrients. Commun. Soil Science and Pl. Anal., 25: 5.

[21] Solomon D. (2008). Presentation On the Relationships Existing in Minerals Soil Between $\mathrm{pH}$ On the One Hand and the Activity of Microorganisms and the Availability of Plant Nutrients On the Other. Bahir Dar University, Bahir Dar, Ethiopia.

[22] Sosulski, T. (2004). Estimation of liming and gypsum conservation division, USDA handbook No. 18. Usapplication on the content of exchangeable aluminum government printing office. Washington, D. C,: USA in sandy soil (in Polish).

[23] Taye, B. (2008). Estimation of Lime Requirment. Training Manual for Regional Soil Testing Laboratory Heads and Technicians. National Soil Testing Center, Ministry of Agriculture and Rural Development.

[24] Tekalign, B. (1992). Intensive training for soil laboratory technicians: Soil analysis on CEC, exchangeable base and calcium carbonate. National Soil Research Center. Addis Ababa, Ethiopia. 
[25] Temesgen D. et al (2015). Effects of short-rotation Eucalyptus plantations on soil quality attributes in highly acidic soils of the central highlands of Ethiopia.

[26] Tilahun D,. (2004). Soil fertility status with emphasis on some micronutrients in vegetable growing areas of Kolfe, Addis Ababa, Ethiopia. M. Sc. Thesis Submitted to School of Graduate Studies, Haramaya University, Ethiopia.

[27] Van Lierop, W. (1991). Testing soils for $\mathrm{pH}$ and lime requirement. New York: Soil Science Society American Process.

[28] Walkley, A. F. (1934). An examination of the Degtjareff method for determining soil organic matter and a proposed modification of the chromic acid titration method. Soil Science Journal Vol. 6 pp 186-189.

[29] Wilding, L. (1985). Soil spatial variability: Its documentation, accommodation and implication to soil surveys, Soil Spatial Variability Proceedings of a Workshop of the ISSS and the SSA, Las Vegas PUDOC.

[30] Yihenew, G. (2002). Selected chemical and physical characteristics of soils Adet Research Center and its Testing Sites in North-Western Ethiopia. Ethiopian Journal of Natural Resources. 